\title{
Judah Benjamin: the Confederate barrister
}

\author{
by Catharine MacMillan
}

$\mathrm{B}$ etween 1811 and 1884 Judah Benjamin led a most remarkable life. His contributions both to American history and English law are significant but still lack a detailed assessment despite several good biographies. Born in St Croix during the British occupation to Sephardic Jewish parents, Benjamin moved as a child to South Carolina. His early years were marked by frequent moves necessitated by his father Philip's lack of commercial success as a merchant. The oldest of seven children, the young Benjamin was later remembered by his childhood contemporaries as a boy too serious to play and one always at the head of his class. At 14 the young Judah left school and travelled north to study at Yale. Here his academic excellence continued but he seems to have fallen into bad company with the result that he left Yale in 1828. Although not expelled, some form of disgrace attended his sudden departure. The events seem to have caused a permanent rift between Benjamin and his father. It was in these circumstances that Judah arrived, on his own, in New Orleans, famously with less than $\$ 5$ in his pocket. He was 16 .

Benjamin went to New Orleans because it offered enormous opportunities for success. At the mouth of the Mississippi River it was then one of the busiest ports in the world, engaged in the shipping of American commodities across the Atlantic. Between 1830 and 1840 its population doubled. Benjamin began work in a commercial firm and then as a clerk at a notary's office. He learned Spanish and French and studied law at night. At 21 years he was called to the Bar of Louisiana and married a Creole beauty, the teenage Marie Augustine Natalie St. Martin de la Caze. Their marriage was an unusual one; they lived apart for most of their married lives when Natalie moved to Paris in the 1840 s with their only child, Ninette. The nature of the marriage is difficult to assess for Benjamin was a notoriously secretive man who destroyed all his papers and Natalie is an even more elusive figure.

Whatever the state of his marriage, Benjamin's professional career moved from one success to another. He ran his legal practice in the centre of New Orleans, located between the French Quarter and the newer businesses run by Americans. He involved himself in commercial litigation in the busy river port of New Orleans. It was in this capacity that Benjamin became well acquainted with a wide range of legal systems. Louisiana had belonged to France from 1682 until 1762, to Spain for the next 40 years, and then for three years to France (again) until it was sold to the United States in 1803. The result was that by the midnineteenth century, the legal system was a mix of Spanish law, pre-Revolutionary French law, Code Napoleon and common law. Benjamin had, thus, a wide understanding and experience of different legal systems. Benjamin became one of the most successful advocates at the bar, specialising in commercial cases and, particularly, in appeals. At 35 he was considered by his contemporaries to be the commercial lawyer of New Orleans.

To this legal success, Benjamin added political success. He became involved with the politically powerful Slidell brothers, Thomas and John. In 1842 Benjamin became a Whig member in the Louisiana legislature. In the 1840s, he bought a sugar plantation outside New Orleans at Bellechasse. The plantation was a substantial concern with 140 slaves. Benjamin built a grand mansion at the plantation and moved some of his family members, including his mother, to the plantation. His involvement was more than ornamental for his poured his energies into sugar production and invented a new process for converting cane juice into pure sugar. He was to sell the plantation, supposedly to assist a friend when a debt Benjamin had guaranteed came due.

In 1852 Benjamin embarked on another level of his political career when he became one of the two United States Senators for Louisiana. In Washington, Benjamin combined his political career with frequent and successful appearances before the United States Supreme Court where he was counsel in a number of significant cases. President Fillmore made him the first Jewish nomination to the Supreme Court but Benjamin declined a judicial role, preferring to focus upon his much more lucrative legal practice. Within the Senate, Benjamin became known as one of the leading Southern orators to speak in defence of states' rights. The particular right Benjamin defended was the right to slavery. Benjamin, along with his fellow Louisianan Senator John Slidell, left his Senate seat in February, 1861 when Louisiana seceded from the Union.

Benjamin was promptly invited by Jefferson Davis to join the Cabinet of the Confederate States of America. The 
two had met during their time in Washington and, although their relationship was initially a hostile one, the pair had become close. Davis admired Benjamin's intellectual capabilities and his capacity for hard work. Within the Confederate Cabinet Benjamin was to hold three posts, each in an area Davis considered critical at the time. Benjamin began as the Attorney General at a point at which it appeared possible to negotiate some sort of accord with the United States. He was then moved to be minister of war on the outbreak of hostilities. Here he earned the enmity of more than one Confederate army officer and, in particular, was blamed for the loss of Roanoke Island. It is a measure of Benjamin's loyalty to the Confederate cause that he accepted public opprobrium for this loss rather than reveal the true problem, namely, that the Confederates had been unable to obtain sufficient munitions to protect themselves. After this military disaster Benjamin was made Secretary of State, a post he held until the end. Within the Confederate cabinet, Benjamin had an unusual role. He was considered, even by Lincoln, to be the most able of Davis's advisors and the two enjoyed a close confidence. At the same time, however, Benjamin was disliked and distrusted by many Confederates.

Benjamin stayed with Davis throughout the war. He fled Richmond with him and they travelled together to Georgia. There they parted company and Benjamin, in fear for his life, fled with a price on his head. He was wanted in connection with the assassination of Lincoln. Benjamin's escape was a narrow one, attended with many dangers and one in which he adopted many disguises, travelled by open boat to the Bahamas and averted at least three possible shipwrecks. He was to dine out on the tale for the rest of his life. Benjamin's wits and guile can be seen in that he was one of only two Confederate cabinet members to escape the Union forces.

\section{AN ENGLISH CAREER}

In August 1865, Benjamin arrived in Southampton. It is said by his biographers that he held some money in England, having managed to ship out cotton through the blockade. It is also said that the money was held on deposit at Overend Gurney \& Co and that it was lost when the bank failed. Benjamin himself apparently lived in straightened circumstances, supporting himself by writing columns on international matters for the Telegraph. He seems, however, to have settled on resuming his legal career fairly shortly after his arrival in England and to that end he was admitted as a member of Lincoln's Inn early in 1866. Here, as a man past the meridian of life, he took his dinners with the students. After one term, however, the Benchers dispensed with the need for him to keep further terms and all other requirements. Benjamin was called to the Bar in June 1866. Once called to the Bar, Benjamin chose to practice on the Northern Circuit because it included Liverpool. Here he could make the most of his
New Orleans' connections and his knowledge of mercantile trade - particularly cotton. In retrospect and with knowledge of his success, it is hard to imagine the obstacles Benjamin had to overcome. He was a complete outsider: American, Jewish, middle-aged and seemingly unconnected to those sources of success at the Bar.

Perseverance was to pay off, though, and Benjamin began his career defending two Confederate agents, Charles Kuhn Prioleau and Colin McRae, in suits brought against them in England by the United States government. The United States sought to recover various Confederate assets allegedly held by the pair. Benjamin's defence had a number of significances, one of which was that it appears to have brought him (and his abilities) to the attention of English solicitors. Benjamin also set about writing a treatise on the sale of goods. The full title of the resulting work was A Treatise on the Law of Sale of Personal Property; with References to the American Decisions and to the French Code and Civil Law; modern lawyers know its descendant as Benjamin on the Sale of Goods. There can be little doubt that the treatise affected the course of English legal development. This author has argued elsewhere that Benjamin's treatise had a significant effect on how English law came to consider contractual mistake. Other instances exist; many more remain to be discovered. The primary motivation for creating the treatise, however, was to show case the author's abilities to the English legal world and, in this regard, the work was an enormous success. The first edition was published in 1868, followed by a second in 1873 and, with two co-authors, a third edition in 1883 .

Benjamin never did look back after he published his treatise. It was at that point that he began to consider applying to become a QC; it appears that he applied first in the autumn of 1868 . On July 31, 1869, he was made a Queen's Counsel, but only of the County Palatine of Lancaster. The explanation made for such a limited advancement was the concern that the United States Government would take offence at the conferment of honours upon so senior member of the Confederacy. In 1872, he so impressed Lord Hatherley in the hearing of Potter v Rankin (viewed later as the leading case on abandonment in marine insurance) before the House of Lords that he was given a patent of precedence, taking rank over all future Queen's Counsel. Benjamin never was to receive a QC, although he was always accorded the initials in the law reports. In April, 1875 he was made a Bencher of Lincoln's Inn (a record for a barrister who had not yet been called for nine years). From about this time, he appeared only before the House of Lords, Privy Council and the Court of Appeal, requiring a special fee of 100 guineas to consider any other brief.

While common lawyers remember Benjamin by his treatise on the sale of goods, contemporaries assessed his skills as a barrister more highly than his treatise. It was before appellate courts that Benjamin particularly shone. Here, his intellect, reason and the breadth of his 
knowledge of common and civil law were particularly useful. His preparation for cases was considered exceptionally thorough. He had an ability to reduce complicated cases to clear, simple conclusions. The reported cases in which he appeared contain more than one judicial reference to the ingenuity of his arguments.

Benjamin never received the judicial appointment which would have given him a much greater role in the development of English law in the last quarter of the nineteenth century. The reason for this lack of appointment was never made explicit or public. In 1880 Benjamin, whilst in Paris, fell from a tramcar. Refusing to give up his grasp, he was dragged by the car. His injuries were great. Within a few years he developed diabetes and suffered a heart attack at Christmas, 1882. This forced him to return and, upon the announcement of his retirement in February 1883, had the unusual pleasure of seeing his career written up in the press. By popular request from both Bench and Bar, a special banquet was held for Benjamin at the Inner Temple Hall. Most of the Bench and the leading members of the Bar attended the banquet on 30 June 1883. Benjamin returned to Paris, to the company of his wife and daughter. Plagued by failing health, he died on May 6, 1884.

While Benjamin led an extraordinary and important life marked with significant contributions to law and politics, it is also a life about which little information remains. Benjamin himself was determined to thwart potential biographers and deliberately destroyed all his personal papers. It is unusual that so pivotal a figure would be considered on as few sources as Benjamin has been. While many aspects of his American political existence may never be known, his legal existence and influence is more readily scrutinised through the remaining records. It is to this task that your author has turned.

Catharine MacMillan

Reader in Legal History, Queen Mary, University of London

The author would like to thank the Institute of Advanced Legal Studies for providing her with a Visiting Fellowship, and Queen Mary, University of London, for a sabbatical to undertake research on Benjamin's life.

\title{
Articles for Amicus Curiae
}

Amicus Curiae welcomes contributions, which should be accompanied by the name and contact details of the author. The journal publishes articles on a wide variety of issues, ranging from short pieces of 700-1,200 words and longer articles of 4,000 words of so (the upper limit can be extended where appropriate). Articles should be written in an informal style and without footnotes.

\author{
Anyone interested in submitting a piece should email Julian Harris \\ (julian.harris@sas.ac.uk).
}

